Sains Malaysiana 50(9)(2021): 2819-2832

http://doi.org/10.17576/jsm-2021-5009-25

\title{
Aliran Titik Genangan MHD dan Pemindahan Haba terhadap Permukaan Telap Meregang/Mengecut dalam Nanobendalir Hibrid
}

(MHD Stagnation Point Flow and Heat Transfer towards a Permeable Stretching/Shrinking Surface in a Hybrid Nanofluid)

\author{
ISKANDAR WAINI, ANUAR ISHAK* \& IOAN POP
}

\begin{abstract}
ABSTRAK
Aliran mantap dan pemindahan haba dua matra terhadap titik genangan pada permukaan telap yang meregang/ mengecut dalam nanobendalir hibrid dengan kesan medan magnet dikaji. Persamaan menakluk bagi masalah tersebut dijelmakan kepada satu set persamaan keserupaan dengan menggunakan penjelmaan keserupaan. Persamaan keserupaan yang terhasil kemudiannya diselesaikan secara berangka menggunakan penyelesai masalah nilai sempadan (bvp4c) dalam perisian Matlab. Kesan beberapa parameter terhadap pekali geseran kulit dan nombor Nusselt setempat serta profil halaju dan suhu dibentangkan dan dibincangkan. Keputusan berangka menunjukkan bahawa penyelesaian dual wujud bagi julat tertentu parameter regangan/kecutan dan fluks jisim. Didapati juga bahawa kadar pemindahan haba meningkat dengan peningkatan pecahan isi padu nanozarah tembaga (Cu) dan parameter fluks jisim. Analisis kestabilan dilakukan untuk menentukan kestabilan penyelesaian dual dalam jangka masa panjang dan keputusan menunjukkan bahawa hanya satu daripada penyelesaian tersebut yang stabil manakala yang lain adalah tidak stabil.
\end{abstract}

Kata kunci: Analisis kestabilan; MHD; nanobendalir hibrid; penyelesaian dual; permukaan meregang/mengecut; titik genangan

\section{ABSTRACT}

The steady two-dimensional stagnation point flow and heat transfer past a permeable stretching/shrinking surface in a hybrid nanofluid with magnetic field effects is investigated. The governing equations of the problem are converted into a set of similarity equations by using similarity transformation. The resulting similarity equations are then solved numerically using the boundary value problem solver (bvp 4c) in Matlab software. The effects of several parameters on the skin friction coefficient and the local Nusselt number as well as the velocity and temperature profiles are presented and discussed. Results found that dual solutions exist for a certain range of the stretching/shrinking and mass flux parameters. It is also found that the heat transfer rate increases with the increasing of the copper (Cu) nanoparticle volume fractions and mass flux parameter. A temporal stability analysis is performed to determine the stability of the dual solutions in a long run, and it is shown that only one of them is stable while the other is unstable.

Keywords: Dual solutions; hybrid nanofluid; MHD; stability analysis; stagnation point; stretching/shrinking surface

\section{Pengenalan}

Masalah aliran lapisan sempadan dan pemindahan haba terhadap permukaan meregang/ mengecut telah diteroka oleh para penyelidik sejak beberapa dekad lalu. Ini adalah kerana ia mempunyai aplikasi yang pelbagai dan penting dalam bidang perindustrian dan teknologi seperti penyemperitan aerodinamik lembaran plastik, penarikan dawai, pintalan logam dan penggelekan panas. Kajian perintis masalah aliran mantap dua matra bagi bendalir likat terhadap permukaan pejal selanjar mula dikaji oleh Sakiadis (1961). Crane (1970) adalah penyelidik pertama yang menganalisis aliran mantap dua matra terhadap permukaan 
meregang linear dan memperoleh penyelesaian keserupaan dalam bentuk analisis tertutup. Selain itu, Wang (1990) adalah penyelidik pertama yang melihat perkembangan sejenis aliran pelik yang berlaku disebabkan oleh kecutan apabila beliau mengkaji ciri-ciri filem cecair pada permukaan meregang tak mantap. Aliran permukaan mengecut ini pada dasarnya adalah aliran ke belakang seperti yang dibincangkan oleh Goldstein (1965). Menurut Miklavčič dan Wang (2006), sedutan jisim diperlukan untuk mengekalkan aliran terhadap permukaan mengecut tersebut. Aliran yang disebabkan oleh permukaan mengecut menunjukkan fenomena fizikal yang agak berbeza daripada aliran meregang ke hadapan seperti yang telah dibincangkan oleh Fang et al. (2009).

Selain itu, kajian bagi aliran dua matra titik genangan terhadap permukaan pejal dalam bendalir bergerak mula dianalisis oleh Hiemenz (1911). Beliau menggunakan penjelmaan keserupaan untuk menurunkan persamaan Navier-Stokes kepada persamaan pembezaan biasa tak linear. Kemudian, masalah bagi aliran simetri sepaksi titik genangan telah dipertimbangkan oleh Homann (1936). Kedua-dua masalah bagi aliran dua matra dan simetri sepaksi titik genangan telah dilanjutkan kepada aliran simetri sepaksi tiga matra titik genangan oleh Howarth (1951). Aliran titik genangan menggambarkan gerakan bendalir berhampiran rantau genangan pada permukaan pejal yang wujud dalam kedua-dua situasi sama ada pada permukaan tetap atau bergerak dalam bendalir. Perlu dinyatakan bahawa Wang (2008) adalah antara penyelidik terawal yang mengkaji aliran simetri sepaksi dua matra bagi titik genangan terhadap kedua-dua permukaan meregang dan mengecut dan beliau mendapati bahawa penyelesaian untuk kes permukaan mengecut adalah tidak unik. Untuk kes aliran lapisan sempadan bagi titik genangan terhadap permukaan mengecut, faktor sedutan jisim tidak lagi perlu untuk mengekalkan aliran kerana wujudnya halaju aliran bebas yang dapat mengatasi pusaran yang terbentuk oleh permukaan mengecut dalam aliran lapisan sempadan. Terdapat ramai penyelidik telah memperluaskan kajian bagi masalah aliran titik genangan kepada aspek berbeza yang boleh didapati dalam kepustakaan seperti Bachok dan Ishak (2011), Bachok et al. (2011), Ishak et al. (2008), Kamal et al. (2019), Kechil dan Hashim (2009), Lok et al. (2011), Mohamed et al. (2012), Rashidi dan Erfani (2011), Rosali et al. (2011), Roşca et al. (2012, 2014), Soid et al. (2018), Yih (1998) dan Zaimi dan Ishak (2012).
Permasalahan yang melibatkan peningkatan pemindahan haba adalah perkara penting dalam aplikasi kejuruteraan dan perindustrian sejak kebelakangan ini. Dalam hal ini, kajian intensif telah dijalankan oleh para penyelidik untuk mengatasi masalah yang dihadapi. Lazimnya, aplikasi penyejukan cecair berprestasi tinggi menggunakan bendalir asas seperti air, etilena glikol dan minyak sebagai bendalir pemindahan haba. Malangnya, bendalir asas ini mempunyai kekonduksian terma yang rendah dan seterusnya mengehadkan peningkatan pemindahan haba. Oleh itu, Choi dan Eastman (1995) adalah penyelidik terawal yang memperkenalkan sejenis bendalir pemindahan haba yang dikenali sebagai nanobendalir untuk meningkatkan kekonduksian terma bendalir asas. Nanobendalir terdiri daripada sebilangan kecil nanozarah yang terampai dalam bendalir asas. Walau bagaimanapun, dengan inovasi dalam bidang sains dan teknologi, nanobendalir hibrid telah dibangunkan dan dipercayai boleh memberi sifat terma dan tingkah laku reologi bersama-sama dengan sifat pemindahan haba yang lebih baik berbanding nanobendalir biasa. Nanobendalir hibrid adalah lanjutan daripada nanobendalir biasa yang terdiri daripada dua jenis nanozarah berbeza yang disebarkan dalam bendalir asas. Nanobendalir hibrid ini menarik ramai penyelidik untuk mengkaji kesan komposit nano yang berbeza dalam pelbagai aplikasi pemindahan haba seperti penukar haba, penenggelam haba, pengumpul suria, pendidihan dan penjanaan kuasa mikro.

Kajian berangka telah dijalankan terhadap aliran nanobendalir hibrid dan pemindahan haba oleh para penyelidik sebagai suatu sumbangan baharu dalam masalah aliran lapisan sempadan dan pemindahan haba. Sebagai contoh, kajian terhadap aliran nanobendalir hibrid $\mathrm{Cu}-\mathrm{Al}_{2} \mathrm{O}_{3}$ /air terhadap permukaan telap meregang dengan kehadiran medan magnet diselidik oleh Devi dan Devi (2016). Mereka mendapati bahawa kadar pemindahan haba nanobendalir hibrid adalah lebih tinggi jika dibandingkan dengan nanobendalir biasa dengan adanya kesan medan magnet. Selepas itu, Devi dan Devi (2017) mengkaji peningkatan pemindahan haba bagi aliran nanobendalir hibrid $\mathrm{Cu}-\mathrm{Al}_{2} \mathrm{O}_{3}$ /air pada permukaan meregang. Peningkatan pemindahan haba terhadap nanobendalir hibrid $\mathrm{Ag}-\mathrm{CuO} /$ air telah dilaporkan oleh Hayat dan Nadeem (2017). Kemudian, Hayat et al. (2018) mengkaji masalah terhadap aliran berputar bagi nanobendalir hibrid $\mathrm{Ag}-\mathrm{CuO} / \mathrm{H}_{2} \mathrm{O}$ dengan kesan sinaran terma dan gelinciran sempadan separa. Yousefi et al. 
(2018) mengkaji aliran titik genangan bagi nanobendalir hibrid titania-tembaga terhadap silinder bergelombang. Masalah aliran tak mantap dan pemindahan haba terhadap permukaan meregang/mengecut dalam nanobendalir hibrid dikaji oleh Waini et al. (2019a). Mereka mendapati bahawa penyelesaian dual wujud bagi julat tertentu parameter ketidakmantapan. Analisis kestabilan juga dilakukan untuk menentukan kestabilan penyelesaian dual yang diperoleh dan menunjukkan cuma satu penyelesaian tersebut stabil manakala yang lain adalah tidak stabil. Akhir-akhir ini, ramai penyelidik mengkaji tingkah laku aliran dan ciri-ciri pemindahan haba bagi nanobendalir hibrid dengan mempertimbangkan pelbagai aspek yang terdapat dalam kepustakaan contohnya seperti Dinarvand (2019), Ghadikolaei et al. (2017), Jamshed dan Aziz (2018), Rostami et al. (2018), Subhani dan Nadeem (2018), Usman et al. (2018) dan Waini et al. (2019b, 2019c, 2019d). Selain itu, hasil kajian terhadap nanobendalir atau nanobendalir hibrid boleh didapati di dalam buku oleh Das et al. (2007) dan dalam kajian makalah ulasan seperti Ahmadi et al. (2018), Akilu et al. (2016), Babu et al. (2017), Das (2017), Huminic dan Huminic (2018), Leong et al. (2017), Mahian et al. (2019a, 2019b), Sajid dan Ali (2018, 2019), Sarkar et al. (2015), Sidik et al. (2016) dan Sundar et al. (2017).

Didorong oleh kajian-kajian ini, makalah ini bertujuan untuk mengkaji masalah aliran titik genangan dan pemindahan haba bagi nanobendalir hibrid terhadap permukaan telap meregang/mengecut dengan kesan medan magnet menggunakan model persamaan nanobendalir yang dicadangkan oleh Tiwari dan Das (2007). Model ini menganalisis tingkah laku nanobendalir hibrid dengan mengambil kira pecahan isi padu pepejal nanozarah. Dalam kajian ini, nanobendalir hibrid dipertimbangkan dengan mengampai dua jenis nanozarah berbeza iaitu alumina $\left(\mathrm{Al}_{2} \mathrm{O}_{3}\right)$ dan tembaga $\mathrm{Cu}$ dalam bendalir asas. Persamaan menakluk dengan syarat-syarat sempadan diturunkan kepada sistem persamaan pembezaan biasa menggunakan penjelmaan keserupaan. Sistem persamaan yang terhasil kemudiannya diselesaikan secara berangka menggunakan penyelesai masalah nilai sempadan (bvp4c) dalam perisian Matlab. Kesan beberapa parameter terhadap tingkah laku aliran dan pemindahan haba dibentangkan dalam bentuk grafik. Perbandingan keputusan dibuat dengan hasil yang terdapat dalam kepustakaan untuk mengesahkan keputusan berangka yang diperoleh.

\section{FORMULASI MATEMATIK}

Pertimbangkan aliran mantap titik genangan dan pemindahan haba terhadap permukaan telap meregang/ mengecut dalam nanobendalir hibrid seperti yang ditunjukkan dalam Rajah 1. Koordinat Cartesan $x$ dan $y$ diambil dengan titik asalan $O$ pada titik genangan dan ditakrifkan supaya paksi $x$ diukur sepanjang permukaan dan paksi $y$ diukur normal pada permukaan tersebut. Diandaikan bahawa halaju aliran bebas diberikan oleh $u_{e}$ $(x)=a x$, dengan $a>0$ adalah kekuatan aliran genangan, manakala halaju permukaan meregang/mengecut diberikan oleh $u_{w}(x)=b x$, yang $\mathrm{b}$ adalah kadar regangan, dengan $b>0$ dan $b<0$ adalah masing-masing untuk kes regangan dan kecutan dan $\mathrm{B}_{0}$ adalah medan magnet yang dikenakan secara luaran pada arah paksi $y$. Di samping itu, diandaikan juga bahawa nombor magnet Reynolds adalah kecil supaya medan magnet yang teraruh diabaikan dan tiada medan elektrik wujud. Nanobendalir hibrid mempunyai suhu persekitaran malar $T_{\infty}$, dengan permukaan meregang/mengecut berada pada suhu malar $T_{w}$. Dengan mempertimbangkan nanobendalir hibrid, dianggap bahawa saiz nanozarah adalah seragam dan kesan penggumpalan nanozarah terhadap sifat termofizikal diabaikan kerana nanobendalir disintesis sebagai campuran stabil yang dihasilkan daripada bendalir asas dan juga nanozarah.

Dengan andaian ini dan juga menggunakan penghampiran lapisan sempadan, persamaan lapisan sempadan yang menakluk nanobendalir hibrid bagi persamaan keselanjaran, momentum dan tenaga diberikan sebagai (Devi dan Devi (2016), Rostami et al. (2018) \& Yousefi et al. (2018)):

$$
\begin{aligned}
& \frac{\partial u}{\partial x}+\frac{\partial v}{\partial y}=0 \\
& u \frac{\partial u}{\partial x}+v \frac{\partial u}{\partial y}=u_{e} \frac{d u_{e}}{d x}+\frac{\mu_{h n f}}{\rho_{h n f}} \frac{\partial^{2} u}{\partial y^{2}}-\frac{\sigma_{h n f}}{\rho_{h n f}} B_{0}^{2}\left(u-u_{e}\right) \\
& u \frac{\partial T}{\partial x}+v \frac{\partial T}{\partial y}=\frac{k_{h n f}}{\left(\rho C_{p}\right)_{h n f}} \frac{\partial^{2} T}{\partial y^{2}}
\end{aligned}
$$

tertakluk kepada syarat-syarat sempadan: 


$$
\begin{aligned}
& v=v_{w}, \quad u=u_{w}(x), T=T_{w} \quad \text { pada } y=0 \\
& u \rightarrow u_{e}(x), \quad T \rightarrow T_{\infty} \quad \text { apabila } \quad y \rightarrow \infty
\end{aligned}
$$

yang $u$ dan $v$ masing-masing adalah komponen halaju nanobendalir hibrid di sepanjang paksi $x$ dan $y, v_{w}$ fluks jisim permukaan seragam dan $\mathrm{T}$ suhu nanobendalir hibrid. Selanjutnya, $\mu_{h n f}$ adalah kelikatan dinamik, $\rho_{h n f}$ ketumpatan, $k_{h n f}$ kekonduksian terma, $\left(\rho C_{p}\right)_{h n f}$ kapasiti haba dan $\sigma_{h n f}$ kekonduksian elektrik bagi nanobendalir hibrid. Beberapa persamaan untuk menilai sifat termofizikal nanobendalir dan nanobendalir hibrid masingmasing diberikan dalam Jadual 1. Sementara itu, sifat fizikal bendalir asas (air) serta nanozarah hibrid iaitu $\mathrm{Al}_{2} \mathrm{O}_{3}$ dan $\mathrm{Cu}$ diberikan dalam Jadual 2.

Bagi mendapatkan penyelesaian keserupaan bagi persamaan (1)-(3) tertakluk kepada syarat sempadan (4), penjelmaan keserupaan berikut diperkenalkan (Ishak et al. (2008), Rosali et al. (2011) \& Yih (1998)):

$$
\eta=y \sqrt{a / \alpha_{f}}, \quad \psi=\sqrt{a \alpha_{f}} x f(\eta), \quad \theta(\eta)=\frac{T-T_{\infty}}{T_{w}-T_{\infty}}
$$

yang $\psi$ adalah fungsi strim yang ditakrifkan sebagai $u$ $=\partial \psi / \partial \mathrm{y}$ dan $v=-\partial \psi / \partial \mathrm{x}$ yang memenuhi persamaan keselanjaran (1). Oleh itu, halaju berkenaan diungkapkan sebagai:

$$
u=a x f^{\prime}(\eta), \quad v=-\sqrt{a \alpha_{f}} f(\eta)
$$

Oleh itu halaju pemindahan jisim pada permukaan $n=0$ diambil sebagai

$$
v_{w}=-\sqrt{a \alpha_{f}} S
$$

dengan $S=f(0)$ adalah parameter fluks jisim malar dengan $S>0$ mewakili sedutan dan $S<0$ mewakili suntikan bendalir, manakala $S=0$ adalah untuk kes permukaan tak telap dan $\alpha_{f}$ adalah resapan terma bendalir asas.

Dengan menggunakan penjelmaan keserupaan (5), persamaan (2) dan (3) tertakluk kepada syarat sempadan (4) diturunkan kepada persamaan pembezaan biasa berikut:

$$
\operatorname{Pr} \frac{\mu_{h n f} / \mu_{f}}{\rho_{h n f} / \rho_{f}} f^{\prime \prime \prime}+f f^{\prime \prime}+1-f^{\prime 2}-\frac{\sigma_{h n f} / \sigma_{f}}{\rho_{h n f} / \rho_{f}} M^{2}\left(f^{\prime}-1\right)=0
$$

$$
\frac{k_{h n f} / k_{f}}{\left(\rho C_{p}\right)_{h n f} /\left(\rho C_{p}\right)_{f}} \theta^{\prime \prime}+f \theta^{\prime}=0
$$

tertakluk kepada syarat sempadan:

$$
\begin{array}{ll}
f(0)=S, \quad f^{\prime}(0)=\lambda, & \theta(0)=1 \\
f^{\prime}(\eta) \rightarrow 1, \quad \theta(\eta) \rightarrow 0 \quad \text { apabila } \quad \eta \rightarrow \infty
\end{array}
$$

dengan tanda (') menunjukkan pembezaan terhadap $\eta, \operatorname{Pr}$ adalah nombor Prandtl, $M$ parameter magnet malar dan $\lambda$ parameter regangan/kecutan yang ditakrifkan sebagai:

$$
\operatorname{Pr}=\frac{v_{f}}{\alpha_{f}}, \quad M=\sqrt{\frac{\sigma_{f} B_{0}^{2}}{a \rho_{f}}}, \quad \lambda=\frac{b}{a}
$$

dengan $\lambda>0$ mewakili permukaan meregang; $\lambda<0$ permukaan mengecut; dan $\lambda=0$ permukaan pegun. Diperhatikan bahawa dengan menggunakan penjelmaan keserupaan (5), nombor Prandtl Pr muncul dalam persamaan momentum (8) dan sekaligus mempengaruhi kedua-dua hajalu dan suhu bendalir.

Kuantiti fizikal yang dikaji adalah pekali geseran kulit $C_{f}$ dan nombor Nusselt setempat $N u_{x}$ yang diberikan sebagai:

$$
C_{f}=\frac{\tau_{w}}{\rho_{f} u_{e}^{2}}, \quad N u_{x}=\frac{x q_{w}}{k_{f}\left(T_{w}-T_{\infty}\right)}
$$

dengan $\tau_{w}$ adalah tegasan ricih permukaan; dan $q_{w}$ adalah fluks haba permukaan yang ditakrifkan sebagai:

$$
\tau_{w}=\mu_{h n f}\left(\frac{\partial u}{\partial y}\right)_{y=0}, \quad q_{w}=-k_{h n f}\left(\frac{\partial T}{\partial y}\right)_{y=0}
$$

Dengan menggunakan (5), (12) dan (13), diperoleh:

$\operatorname{Re}_{x}^{1 / 2} C_{f}=\operatorname{Pr}^{1 / 2} \frac{\mu_{h n f}}{\mu_{f}} f^{\prime \prime}(0), \quad \operatorname{Re}_{x}^{-1 / 2} N u_{x}=-\operatorname{Pr}^{1 / 2} \frac{k_{h n f}}{k_{f}} \theta^{\prime}(0)(14)$ dengan $R e_{x}=u_{e}(x) x / v_{f}$ adalah nombor Reynolds setempat. Perlu dinyatakan bahawa dengan mempertimbangkan bendalir biasa $\left(\varphi_{1}=\varphi_{2}=0\right)$ tanpa kehadiran medan magnet dan $\operatorname{Pr}=1$, persamaan (8) diturunkan kepada persamaan (3) daripada makalah oleh Wang (2008) dan seterusnya keputusan kajian ini dibandingkan dengan keputusan oleh Wang (2008). 


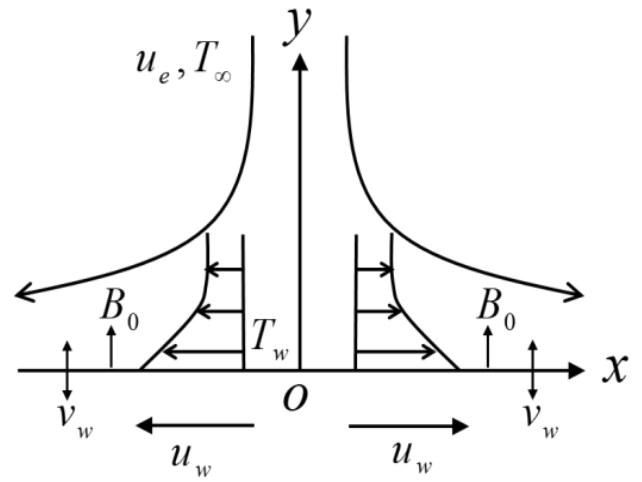

(a) Permukaan meregang

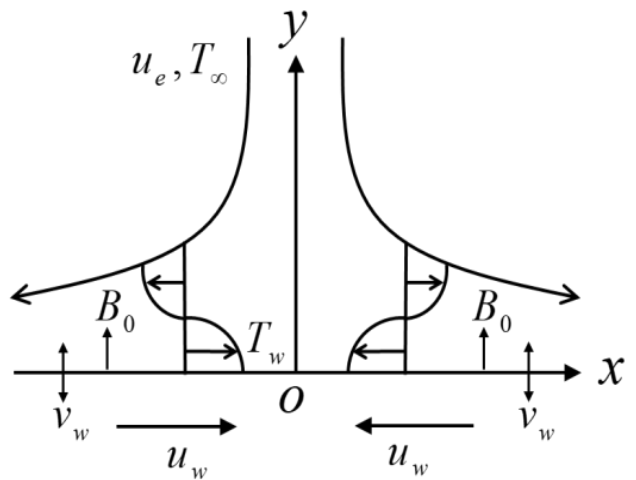

(b) Permukaan mengecut

RAJAH 1. Sistem koordinat dan model fizikal

JADUAL 1. Sifat termofizikal nanobendalir

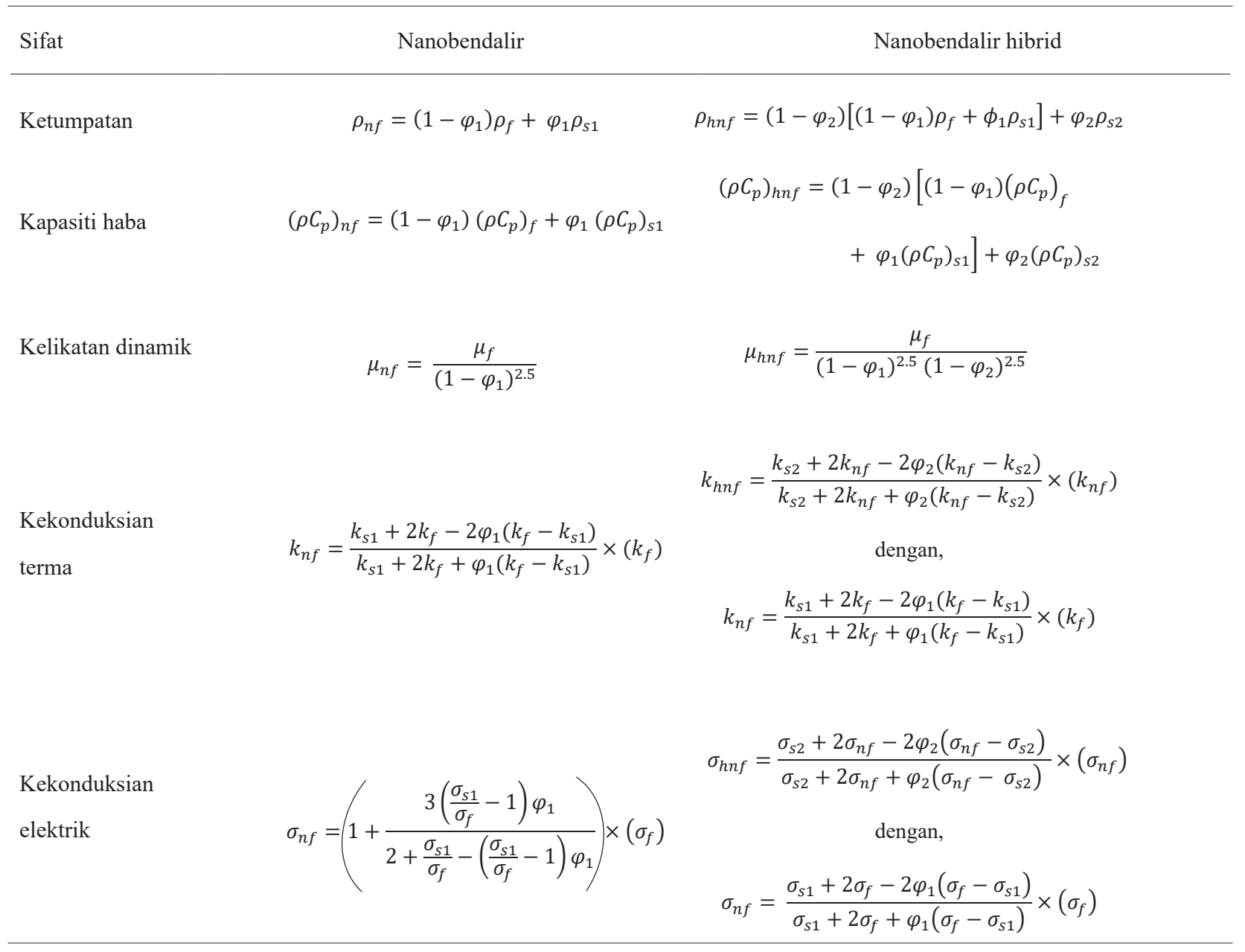

(Devi dan Devi 2016, Khanafer et al. 2003, Oztop dan Abu-Nada 2008 dan Yousefi et al. 2018) 
JADUAL 2. Sifat termo-fizikal bendalir asas dan nanozarah (Oztop \& Abu-Nada 2008; Raza et al. 2016)

\begin{tabular}{lccc}
\hline \multicolumn{1}{c}{ Sifat fizikal } & Bendalir asas (air) & $\mathrm{Al}_{2} \mathrm{O}_{3}$ & $\mathrm{Cu}$ \\
\hline$\rho\left(k g / \mathrm{m}^{\wedge 3}\right)$ & 997.1 & 3970 & 8933 \\
$C_{p}(\mathrm{~J} / \mathrm{kg} K)$ & 4179 & 765 & 385 \\
$k(\mathrm{~W} / \mathrm{m} K)$ & 0.613 & 40 & 400 \\
$\sigma(S / m)$ & 0.05 & $3.69 \times 10^{7}$ & $5.96 \times 10^{7}$ \\
\hline
\end{tabular}

\section{ANALISIS KESTABILAN}

Analisis kestabilan dijalankan untuk menentukan kestabilan penyelesaian dual bagi masalah nilai sempadan (8)-(10). Untuk menguji ciri ini, persamaan tak mantap untuk persamaan (2) dan (3) dipertimbangkan, dengan persamaan (1) kekal tidak berubah. Dalam hal ini, kajian oleh Awaludin et al. (2018), Merkin (1980) dan Weidman et al. (2006) adalah dirujuk. Seperti dalam kajian tersebut, pemboleh ubah masa tak bermatra iaitu $\tau=a t$ diperkenalkan untuk memodelkan masalah kestabilan untuk jangka panjang, $\tau \rightarrow \infty$. Untuk kes aliran tak mantap, pemboleh ubah berikut diperkenalkan:

$$
\begin{aligned}
& \eta=y \sqrt{a / \alpha_{f}}, u=a x \frac{\partial f}{\partial \eta}(\eta, \tau), \\
& v=-\sqrt{a \alpha_{f}} f(\eta, \tau), \theta(\eta, \tau)=\frac{T-T_{\infty}}{T_{w}-T_{\infty}}, \tau=a t
\end{aligned}
$$

Persamaan (8) dan (9) sekarang ditulis sebagai:

$$
\begin{aligned}
& \operatorname{Pr} \frac{\mu_{h n f} / \mu_{f}}{\rho_{h n f} / \rho_{f}} \frac{\partial^{3} f}{\partial \eta^{3}}+f \frac{\partial^{2} f}{\partial \eta^{2}}+1-\left(\frac{\partial f}{\partial \eta}\right)^{2}- \\
& \frac{\sigma_{h n f} / \sigma_{f}}{\rho_{h n f} / \rho_{f}} M^{2}\left(\frac{\partial f}{\partial \eta}-1\right)-\frac{\partial^{2} f}{\partial \eta \partial \tau}=0 \\
& \frac{k_{h n f} / k_{f}}{\left(\rho C_{p)^{n n f}} /\left(\rho C_{p}\right)_{f}\right.} \frac{\partial^{2} \theta}{\partial \eta^{2}}+f \frac{\partial \theta}{\partial \eta}-\frac{\partial \theta}{\partial \tau}=0
\end{aligned}
$$

tertakluk kepada syarat sempadan:

$$
\begin{array}{ll}
f(0, \tau)=S, \quad \frac{\partial f}{\partial \eta}(0, \tau)=\lambda, & \theta(0, \tau)=1 \\
\frac{\partial f}{\partial \eta}(\eta, \tau) \rightarrow 1, \quad \theta(\eta, \tau) \rightarrow 0 \quad \text { apabila } \quad \eta \rightarrow \infty
\end{array}
$$

Untuk menguji kestabilan bagi penyelesaian aliran mantap $f(\eta)=f_{0}(\eta)$ dan $\theta(\eta)=\theta_{0}(\eta)$ yang memenuhi masalah nilai sempadan (8)-(10), hubungan berikut digunakan (Soid et al. (2018) dan Weidman et al. (2006)):

$f(\eta, \tau)=f_{0}(\eta)+e^{-\gamma \tau} F(\eta), \quad \theta(\eta, \tau)=\theta_{0}(\eta)+e^{-\gamma \tau} G(\eta)$

dengan $\gamma$ adalah parameter nilai eigen, dan $F(\eta)$ dan $G(\eta)$ adalah kecil relatif terhadap $f_{0}(\eta)$ dan $\theta_{0}$ $(\eta)$. Gantikan (19) ke dalam persamaan (16) dan (17), persamaan linear nilai eigen berikut diperoleh:

$$
\begin{aligned}
& \operatorname{Pr} \frac{\mu_{h n f} / \mu_{f}}{\rho_{h n f} / \rho_{f}} F^{\prime \prime \prime}+f_{0} F^{\prime \prime}+f_{0}^{\prime \prime} F-2 f_{0}^{\prime} F^{\prime} \\
& -\frac{\sigma_{h n f} / \sigma_{f}}{\rho_{h n f} / \rho_{f}} M^{2} F^{\prime}+\gamma F^{\prime}=0
\end{aligned}
$$

$$
\frac{k_{h n f} / k_{f}}{\left(\rho C_{p}\right)_{h n f} /\left(\rho C_{p}\right)_{f}} G^{\prime \prime}+f_{0} G^{\prime}+\theta_{0}^{\prime} F+\gamma G=0
$$

tertakluk kepada syarat sempadan:

$$
\begin{array}{ll}
F(0)=0, & F^{\prime}(0)=0, \quad G(0)=0 \\
F^{\prime}(\eta) \rightarrow 0, & G(\eta) \rightarrow 0 \quad \text { apabila } \quad \eta \rightarrow \infty
\end{array}
$$

Untuk nilai parameter menakluk tertentu, kestabilan penyelesaian aliran mantap yang sepadan dengan $f_{0}(\eta)$ dan $\theta_{0}(\eta)$ ditentukan oleh nilai eigen $\gamma$ yang terkecil. Julat yang mungkin bagi nilai eigen $\gamma$ boleh ditentukan dengan merehatkan satu daripada syarat sempadan $F(\eta)$ 
atau $G(\eta)$ seperti yang dicadangkan oleh Harris et al. (2009). Oleh tu, syarat sempadan yang direhatkan adalah $F^{\prime}(\eta) \rightarrow 0$ apabila $\eta \rightarrow \infty$ dan diganti dengan $F^{\prime \prime}(0)=1$. Jadi, keputusan bagi analisis kestabilan dalam makalah ini adalah untuk kes $F^{\prime \prime}(0)=1$. Untuk satu nilai eigen $\gamma$ yang ditetapkan, sistem persamaan (20) dan (21) bersama-sama dengan syarat perlu diselesaikan.

\section{HASIL DAN PERBINCANGAN}

Penyelesai masalah nilai sempadan yang terdapat dalam perisian Matlab yang dikenali sebagai 'bvp4c' digunakan untuk menyelesaikan persamaan pembezaan biasa tak linear (8) dan (9) bersama-sama dengan syarat sempadan (10) secara berangka. Penyelesai 'bvp4c' ini terkenal di kalangan ramai penyelidik dan telah banyak digunakan untuk menyelesaikan masalah nilai sempadan contohnya seperti Awaludin et al. (2018), Dinarvand (2019), Jusoh et al. (2019), Kamal et al. (2019), Khashi'ie et al. (2019), Rostami et al. (2018), Soid et al. (2018), Waini et al. (2019e) dan Yousefi et al. (2018). Bagi mendapatkan penyelesaian berangka dengan kaedah ini, adalah perlu untuk membuat tekaan awal pada titik jejaring awalan dan menukar saiz langkah. Tekaan awal dan ketebalan lapisan sempadan $\eta_{\infty}$ yang sesuai harus dipilih bergantung pada nilai-nilai parameter yang digunakan. Tekaan awal bagi penyelesaian pertama (cabang atas) adalah lebih mudah kerana kaedah bvp4c akan menumpu kepada penyelesaian pertama walaupun dengan tekaan awal yang lemah. Walau bagaimanapun, agak sukar untuk menentukan tekaan awal bagi penyelesaian kedua (cabang bawah). Dalam kes ini, teknik kesinambungan diperlukan untuk menentukan tekaan awal tersebut. Untuk menyelesaikan masalah nilai sempadan ini, sistem persamaan perlu diturunkan kepada sistem persamaan pembezaan biasa terbitan pertama. Butiran terperinci bagi kaedah ini boleh didapati di dalam buku oleh Shampine et al. (2003).

Perbandingan keputusan berangka kajian ini dengan kajian terdahulu dipaparkan pada Jadual 3 dan 4. Kesan beberapa parameter terhadap pekali geseran kulit dan nombor Nusselt setempat serta profil halaju dan suhu dibentangkan dalam bentuk grafik menerusi Rajah 2 hingga 15. Seperti yang dicadangkan oleh Devi dan Devi (2017), nanozarah $\mathrm{Al}_{2} \mathrm{O}_{3}\left(\varphi_{1}\right)$ ditambah ke dalam bendalir asas (air) dengan 0.1 pecahan isi padu pepejal (iaitu $\varphi_{1}=$ $0.1)$ dan seterusnya $\mathrm{Cu}\left(\varphi_{2}\right)$ ditambah dengan pelbagai pecahan isi padu pepejal untuk membentuk nanobendalir hibrid iaitu $\mathrm{Cu}-\mathrm{Al}_{2} \mathrm{O}_{3}$ /air. Mengikuti Khanafer et al. (2003) dan Oztop dan Abu-Nada (2008), keputusan berangka yang diperoleh adalah untuk kes nombor Prandtl $\operatorname{Pr}=6.2$, mewakili bendalir asas air yang digunakan sepanjang kajian ini. Nilai $\mathrm{Pr}=6.2$ mewakili air pada ketetapan suhu bilik $25^{\circ} \mathrm{C}$.

Jadual 3 mewakili nilai - $\theta^{\prime}(0)$ bagi bendalir biasa $\left(\varphi_{1}=\varphi_{2}=0\right)$ dengan pelbagai nilai $S$ dan $M$ apabila $\lambda=0$ dan $\operatorname{Pr}=1$. Hasil keputusan berangka kajian ini menunjukkan penyelesaian yang serupa dengan penyelesaian yang diperoleh oleh Yih (1998), Kechil dan Hashim (2009) dan Rashidi dan Erfani (2011). Selain itu, Jadual 4 disediakan untuk menunjukkan nilai perbandingan $f^{\prime \prime}(0)$ bagi nanobendalir $\mathrm{Cu}$-air apabila $\varphi_{1}=S=M=0$ dan $\operatorname{Pr}=1$ dengan keputusan yang dilaporkan oleh Bachok et al. (2011) untuk pelbagai nilai $\lambda$ dan $\varphi_{2}$ yang menunjukkan hasil perbandingan yang sangat baik. Sementara itu, keputusan bagi bendalir biasa $\left(\varphi_{1}=\varphi_{2}=0\right)$ yang diperoleh oleh Wang (2008) juga dibandingkan dalam jadual yang sama.

Perubahan pekali geseran kulit dan nombor Nusselt setempat untuk parameter terpilih dibentangkan dalam Rajah 2 hingga 7. Daripada rajah-rajah tersebut, peningkatan pekali geseran kulit dan nombor Nusselt setempat pada permukaan diperhatikan dengan peningkatan $\varphi_{2}$ dan $S$ untuk cabang atas. Didapati juga bahawa penyelesaian dual hanya wujud sehingga nilai kritikal tertentu $\lambda_{c}$ dan $S_{c}$. Nilai kritikal adalah nilai penyelesaian pertama (cabang atas) menghampiri dan bertindih dengan penyelesaian kedua (cabang bawah). Tidak ada penyelesaian keserupaan yang wujud melebihi nilai kritikal ini disebabkan lapisan sempadan telah terpisah daripada permukaan dan penyelesaian menggunakan penghampiran lapisan sempadan tidak lagi sah.

Secara terperinci, Rajah 2 dan 3 menunjukkan perubahan bagi pekali geseran kulit $R e_{x}^{1 / 2} C_{f}$ dan nombor Nusselt setempat $R e_{x}^{1 / 2} N u_{\mathrm{x}}$ terhadap $\lambda$ untuk pelbagai nilai $\varphi_{2}$ apabila $M=\varphi_{1}=0.1, S=0.5$ dan $\operatorname{Pr}=6.2$. Perubahan yang sangat kecil diperhatikan terhadap nilai kritikal $\lambda_{c}$ dengan peningkatan $\varphi_{2}$. Peralihan daripada cabang atas kepada cabang bawah hampir berlaku pada titik yang sama. Berdasarkan pengiraan berangka, nilai kritikal $\lambda$ untuk $\varphi_{2}=0.01,0.05$ dan 0.1 masing-masing adalah $\lambda_{c}=-1.3563,-1.3610$ dan -1.3646 . Kemudian, Rajah 4 dan 5 memaparkan perubahan bagi $\operatorname{Re}_{x}{ }^{1 / 2} C_{f}$ dan $R e_{x}^{1 / 2}$ $N u_{x}$ terhadap $\lambda$ untuk pelbagai nilai $S$ apabila $M=\varphi_{1}=$ 
$\varphi_{2}=0.1$ dan $\operatorname{Pr}=6.2$. Dapat diperhatikan bahawa dengan peningkatan $\mathrm{S}$, julat nilai $\lambda$ turut meningkat dengan nilai kritikan $\lambda_{\text {c }}$ cenderung bergerak sedikit ke kiri. Di sini, nilai kritikal $\lambda$ untuk $S=-0.5,0$ dan 0.5 masing-masing adalah $\lambda_{c}=-1.1625,-1.2541$ dan -1.3646 . Seterusnya, perubahan bagi $R e_{x}^{1 / 2} C_{f}$ dan $R e_{x}^{1 / 2} N u_{x}$ terhadap $S$ untuk pelbagai nilai $\varphi_{1}$ apabila $\lambda=-1.1, \mathrm{M}=\varphi_{1}=0.1 \mathrm{dan} \operatorname{Pr}=$ 6.2 diplot dalam Rajah 6 dan 7. Diperhatikan bahawa nilai kritikal $S$ meningkat dan bergerak sedikit ke kanan apabila $\varphi_{2}$ meningkat. Keputusan mendapati bahawa untuk $\varphi_{2}=0.01$, penyelesaian dual wujud apabila $S_{c} \geq$ -1.0166, manakala untuk $\varphi_{1}=0.05$, penyelesaian dual wujud apabila $S_{c} \geq-0.9620$ dan untuk $\varphi_{1}=0.1, S_{c} \geq$ -0.9249 .

Profil halaju dan suhu untuk parameter terpilih dibentangkan dalam Rajah 8 hingga 15. Dapat diperhatikan bahawa semua profil dalam rajah-rajah ini menunjukkan bahawa ketebalan lapisan sempadan untuk penyelesaian cabang bawah adalah lebih tinggi berbanding penyelesaian cabang atas dan juga profil ini memenuhi syarat sempadan tak terhingga secara asimptot, yang menyokong kesahihan keputusan berangka yang diperoleh. Rajah 8 dan 9 menerangkan kesan $\varphi_{2}$ terhadap profil halaju $f^{\prime}(\eta)$ dan profil suhu $\theta(\eta)$. Diperhatikan bahawa peningkatan $\varphi_{2}$ cenderung meningkatkan halaju dan menurunkan suhu di dalam lapisan sempadan untuk kedua-dua cabang atas dan bawah. Selain itu, Rajah 10 hingga 13 menunjukkan profil halaju $f^{\prime}(\eta)$ dan profil suhu $\theta(\eta)$ bagi pelbagai nilai $\lambda$ dan $S$. Penurunan halaju dan peningkatkan suhu untuk cabang atas dapat dilihat, manakala tingkah laku yang bertentangan diperhatikan untuk cabang bawah dengan penurunan nilai $\lambda$ dan $S$.

Didapati juga bahawa profil untuk penyelesaian cabang atas dan penyelesaian cabang bawah akan menghampiri antara satu sama lain dan bertindih pada nilai kritikal $\lambda_{c}$ dan $S_{c}$ tertentu seperti yang dibentangkan dalam Rajah 2 hingga 7. Kesan parameter magnet $M$ terhadap profil halaju $f^{\prime}(\eta)$ dan profil suhu $\theta(\eta)$ dipamerkan dalam Rajah 14 dan 15. Diperhatikan bahawa peningkatan $M$ cenderung meningkatkan halaju dan menurunkan suhu di dalam lapisan sempadan untuk cabang atas, sementara itu tingkah laku yang bertentangan diperhatikan untuk cabang bawah. Walau bagaimanapun, perubahan yang sangat kecil diperhatikan untuk cabang atas.

Nilai eigen $\gamma$ terkecil untuk pelbagai nilai $\lambda$ apabila $M=\varphi=\varphi_{2}=0.1, S=0.5$ dan $\operatorname{Pr}=6.2$ digambarkan dalam Rajah 16. Berdasarkan persamaan (19), nilai eigen $\gamma$ positif menunjukkan penyusutan gangguan apabila masa berlalu, $\tau \rightarrow \infty$, dan aliran dikatakan berada dalam mod stabil. Sebaliknya, nilai eigen $\gamma$ negatif menunjukkan pertumbuhan gangguan dan aliran adalah tak stabil dalam jangka masa panjang. Jelas sekali, dapat diperhatikan bahawa nilai eigen $\gamma$ yang paling kecil cenderung kepada sifar sama ada dari cabang atas atau cabang bawah apabila nilai $\lambda$ menghampiri $\lambda_{c}$. Ini menunjukkan bahawa peralihan nilai eigen $\gamma$ daripada positif (stabil) kepada negatif (tidak stabil) berlaku pada titik percabangan.

JADUAL 3. Nilai-nilai - $\theta^{\prime}(0)$ bagi bendalir biasa $\left(\varphi_{1}=\varphi_{1}=0\right)$ untuk beberapa nilai $S$ dan $M$ apabila $\lambda=0$ dan $\operatorname{Pr}=1$

\begin{tabular}{|c|c|c|c|c|c|}
\hline$S$ & $M$ & Yih (1998) & Kechil dan Hashim (2009) & Rashidi dan Erfani (2011) & Kajian ini \\
\hline \multirow[t]{3}{*}{-1} & 0 & 0.116752 & 0.11677 & & 0.116752 \\
\hline & 1 & 0.140002 & 0.14000 & & 0.140002 \\
\hline & 2 & 0.173124 & 0.17312 & & 0.173124 \\
\hline \multirow[t]{3}{*}{0} & 0 & 0.570465 & 0.57035 & & 0.570465 \\
\hline & 1 & 0.595346 & 0.59539 & & 0.595346 \\
\hline & 2 & 0.634132 & 0.63418 & & 0.634132 \\
\hline \multirow[t]{3}{*}{1} & 0 & 1.323691 & 1.32368 & 1.3237259 & 1.323691 \\
\hline & 1 & 1.338060 & 1.33804 & 1.3380573 & 1.338060 \\
\hline & 2 & 1.364466 & 1.36446 & 1.3644532 & 1.364466 \\
\hline
\end{tabular}


JADUAL 4. Nilai-nilai $f^{\prime \prime}(0)$ bagi Cu-air nanobendalir untuk beberapa nilai $\lambda$ dan $\varphi_{2}$ apabila $\varphi_{1}=S=M=0$ dan $\operatorname{Pr}=1$

\begin{tabular}{cccccccc}
\hline$\lambda$ & Wang (2008) & \multicolumn{3}{c}{ Bachok et al. (2011) } & \multicolumn{3}{c}{ Kajian ini } \\
\hline & $\varphi_{2}=0$ & $\varphi_{2}=0$ & $\varphi_{2}=0.1$ & $\varphi_{2}=0.2$ & $\varphi_{2}=0$ & $\varphi_{2}=0.1$ & $\varphi_{2}=0.2$ \\
\hline 2 & -1.88731 & -1.887307 & -2.217106 & -2.298822 & -1.887307 & -2.217106 & -2.298822 \\
1 & 0 & 0 & 0 & 0 & 0 & 0 & 0 \\
0.5 & 0.71330 & 0.713295 & 0.837940 & 0.868824 & 0.713295 & 0.837940 & 0.868824 \\
0 & 1.232588 & 1.232588 & 1.447977 & 1.501346 & 1.232588 & 1.447977 & 1.501346 \\
-0.5 & 1.49567 & 1.495670 & 1.757032 & 1.821791 & 1.495670 & 1.757032 & 1.821791 \\
-1 & 1.32882 & 1.328817 & 1.561022 & 1.618557 & 1.328817 & 1.561022 & 1.618557 \\
\hline
\end{tabular}

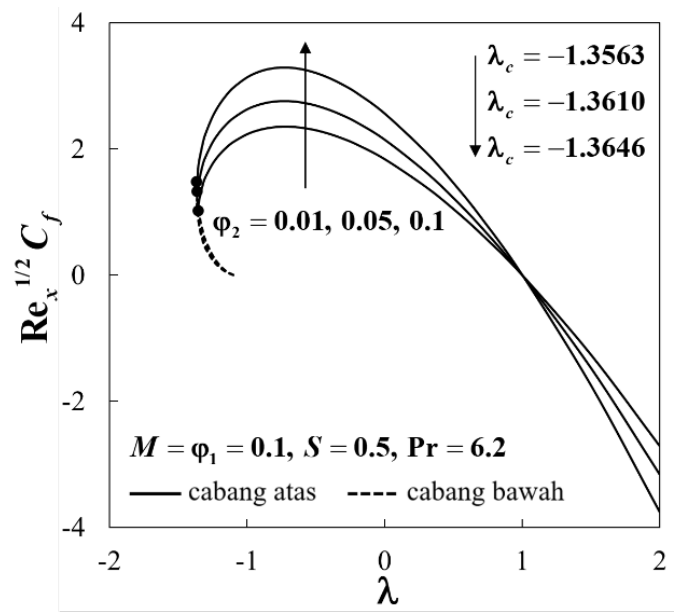

RAJAH 2. Perubahan $\operatorname{Re}_{x}^{1 / 2} C_{f}$ terhadap $\lambda$ untuk beberapa nilai $\varphi_{2}$

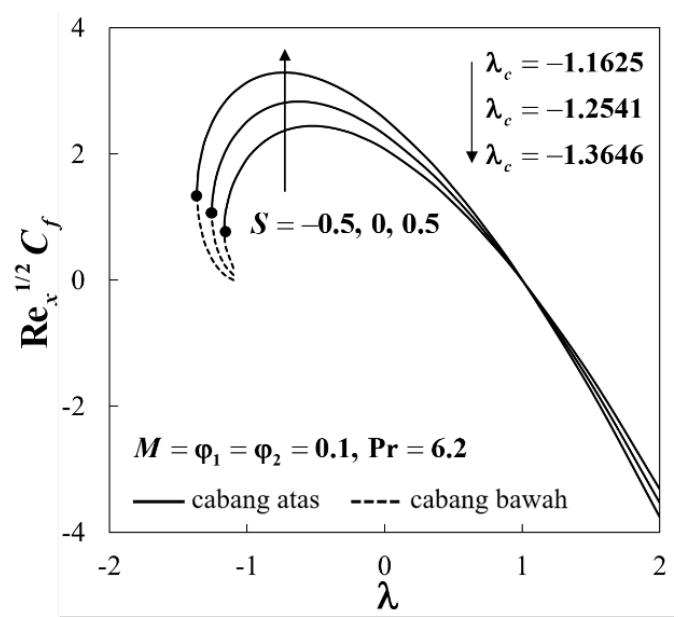

RAJAH 4. Perubahan $R e_{x}^{1 / 2} C_{f}$ terhadap $\lambda$ untuk beberapa nilai $S$

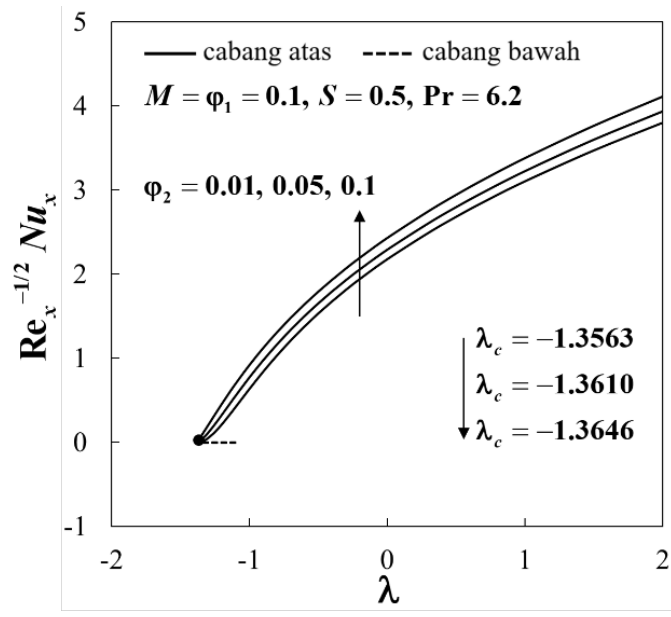

RAJAH 3. Perubahan $R e_{x}^{-1 / 2} N u_{x}$ terhadap $\lambda$ untuk beberapa nilai $\varphi_{2}$

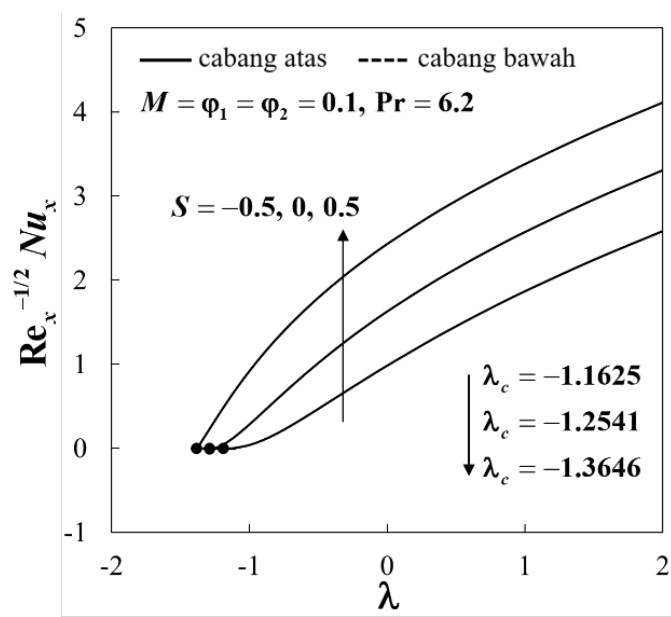

RAJAH 5. Perubahan $R e_{x}^{-1 / 2} N u_{x}$ terhadap $\lambda$ untuk beberapa nilai $S$ 


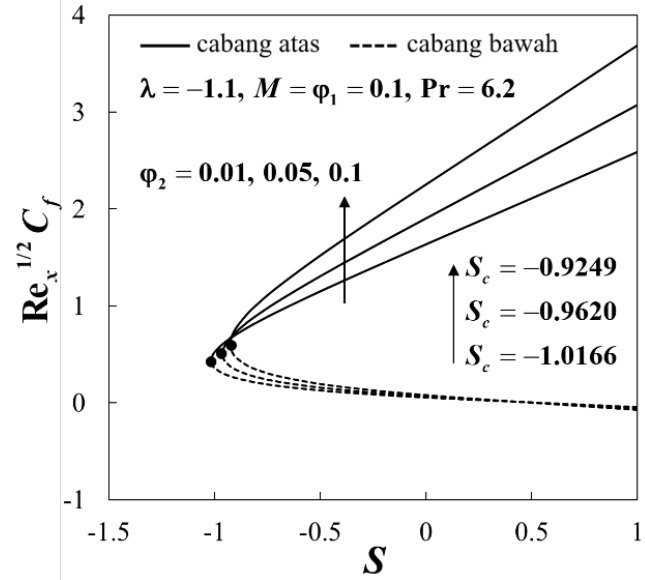

RAJAH 6. Perubahan $R e_{x}^{1 / 2} C_{f}$ terhadap $S$ untuk beberapa nilai $\varphi_{2}$

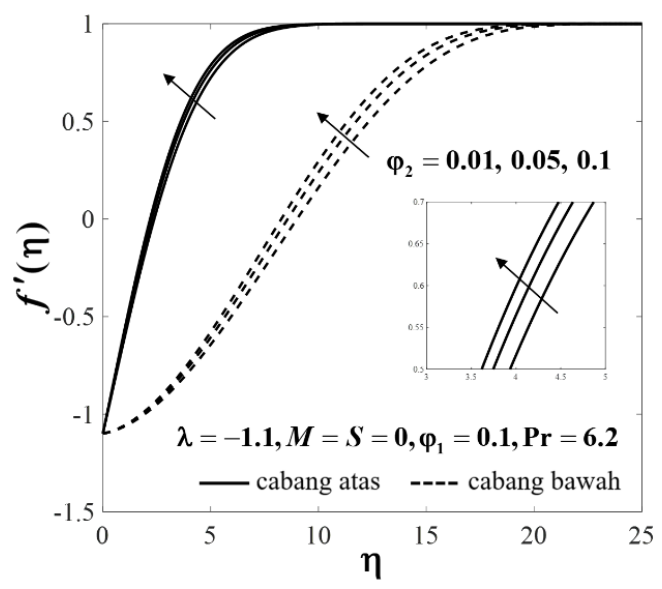

RAJAH 8. Profil halaju $f^{\prime}(\eta)$ untuk beberapa nilai $\varphi_{2}$

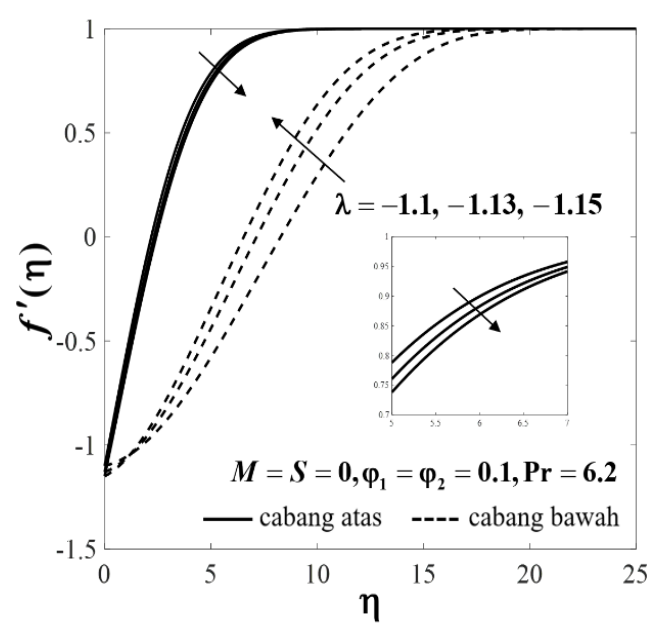

RAJAH 10. Profil halaju $f^{\prime}(\eta)$ untuk beberapa nilai $\lambda$

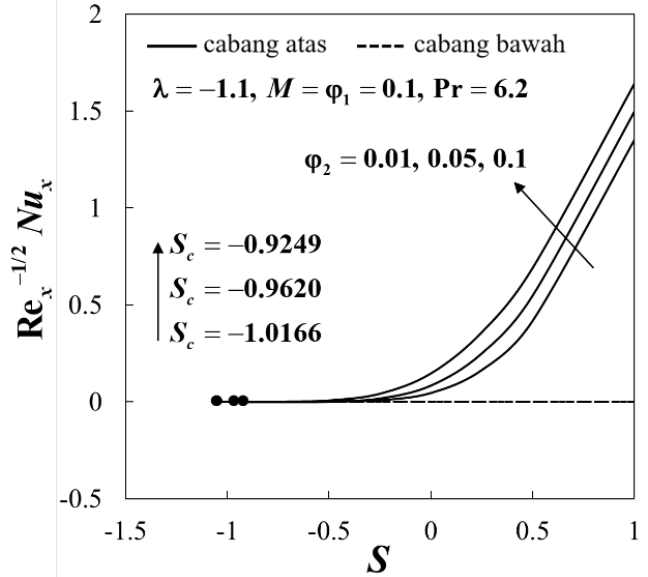

RAJAH 7. Perubahan $R e_{x}^{-1 / 2} N u_{x}$ terhadap $S$ untuk beberapa nilai $\varphi_{2}$

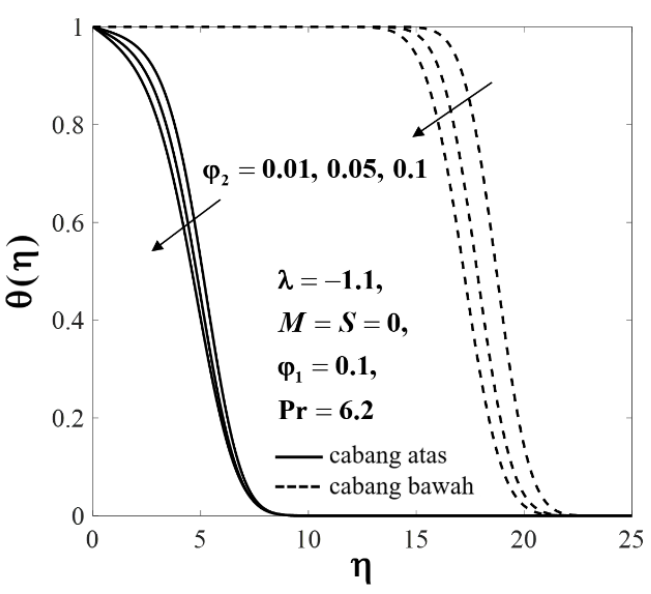

RAJAH 9. Profil suhu $\theta(\eta)$ untuk beberapa nilai $\varphi_{2}$

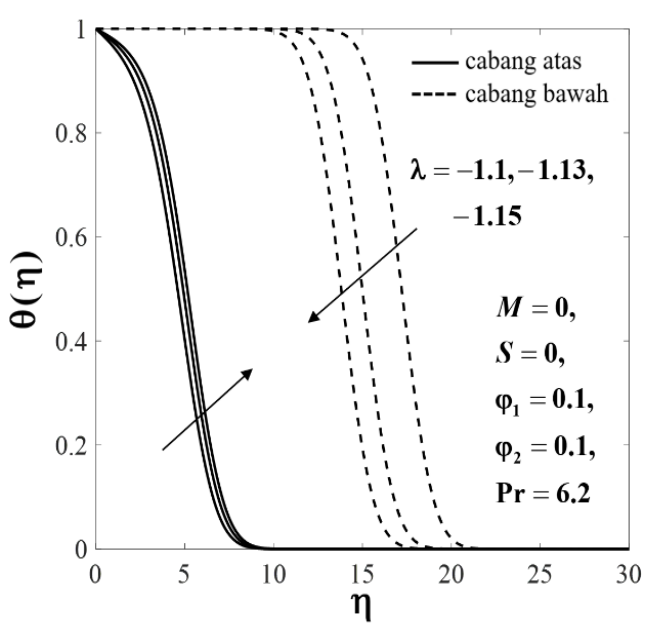

RAJAH 11. Profil suhu $\theta(\eta)$ untuk beberapa nilai $\lambda$ 


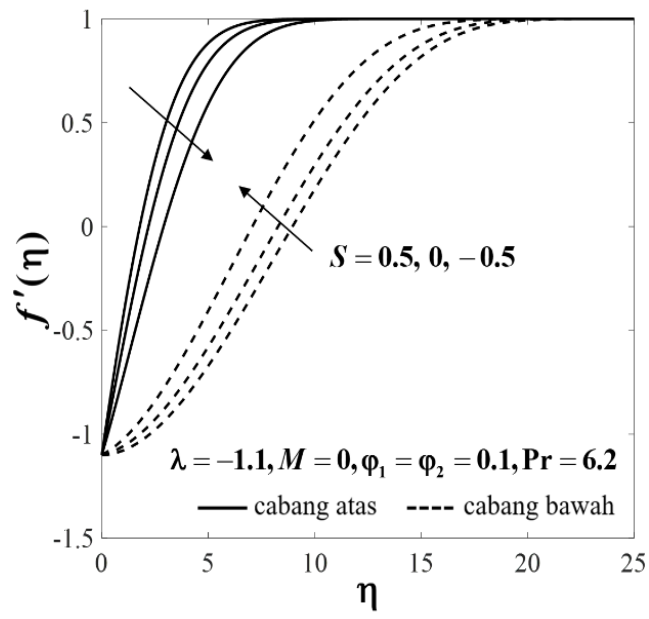

RAJAH 12. Profil halaju $f^{\prime}(\eta)$ untuk beberapa nilai $S$

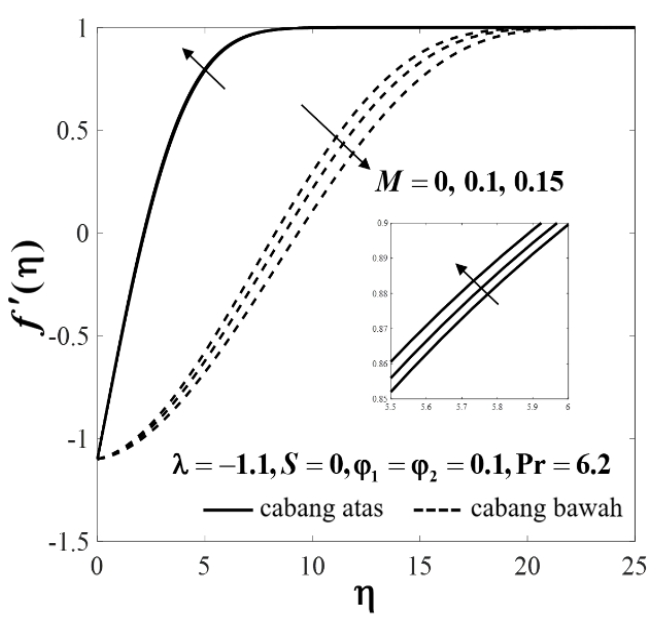

RAJAH 14. Profil halaju $f^{\prime}(\eta)$ untuk beberapa nilai $M$

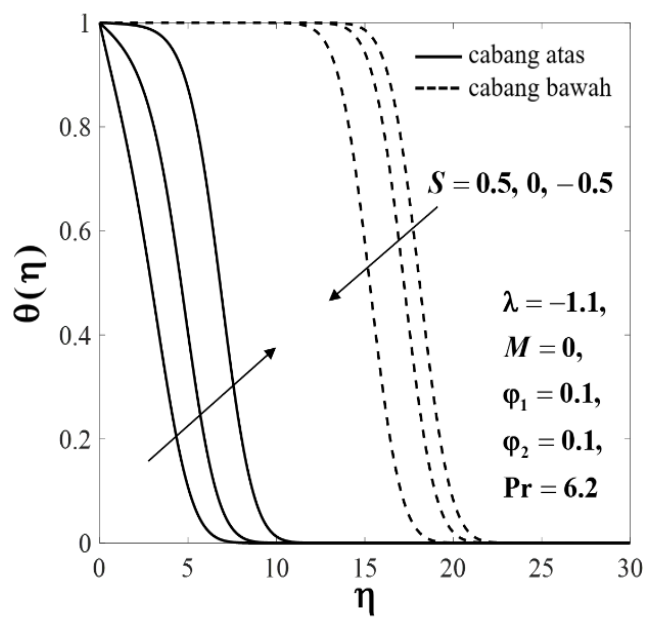

RAJAH 13. Profil suhu $\theta(\eta)$ untuk beberapa nilai $S$

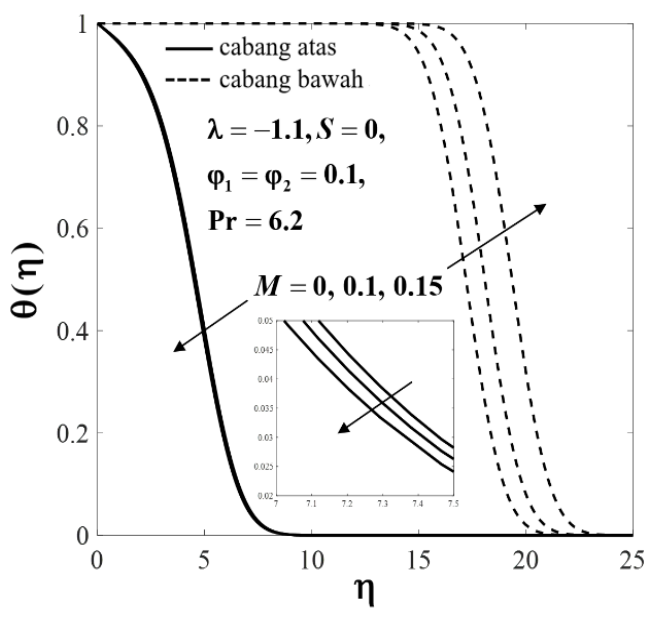

RAJAH 15. Profil suhu $\theta(\eta)$ untuk beberapa nilai $M$

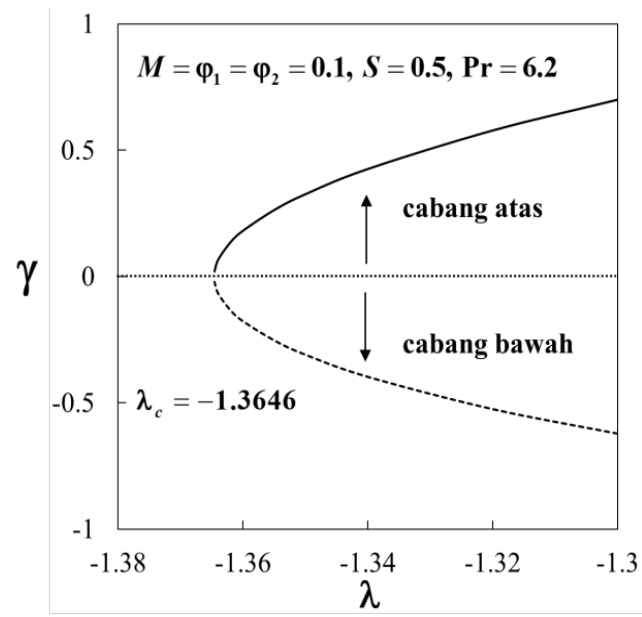

RAJAH 16. Nilai eigen $\gamma$ terkecil untuk beberapa nilai $\lambda$ 


\section{KESIMPULAN}

Dalam makalah ini, aliran titik genangan MHD dan pemindahan haba dalam nanobendalir hibrid terhadap permukaan meregang/mengecut telah dikaji. Perbandingan antara keputusan kajian ini dengan hasil yang terdapat dalam kepustakaan untuk kes tertentu telah dilakukan dan menunjukkan hasil yang sangat baik. Didapati bahawa peningkatan pecahan isi padu nanozarah tembaga $\mathrm{Cu}$ dan parameter fluks jisim telah meningkatkan pekali geseran kulit dan nombor Nusselt setempat pada permukaan. Diperhatikan juga bahawa nilai kritikal parameter regangan/kecutan sedikit berkurangan apabila parameter fluks jisim meningkat. Sementara itu, perubahan yang sangat kecil diperhatikan dalam nilai kritikal parameter regangan/kecutan dengan peningkatan pecahan isi padu nanozarah tembaga $(\mathrm{Cu})$ dengan peralihan daripada cabang atas kepada cabang bawah hampir berlaku pada titik percabangan yang sama. Selain itu, nilai kritikal parameter fluks jisim bertambah apabila pecahan isi padu nanozarah tembaga $(\mathrm{Cu})$ meningkat. Peningkatan pecahan isi padu nanozarah tembaga $(\mathrm{Cu})$ cenderung meningkatkan halaju dan menurunkan suhu di dalam lapisan sempadan untuk kedua-dua cabang. Didapati bahawa kedua-dua cabang untuk halaju dan suhu menghampiri satu sama lain untuk nilai-nilai parameter regangan/kecutan dan fluks jisim yang lebih kecil. Halaju dan suhu di dalam lapisan sempadan sangat sedikit terjejas dengan kehadiran kesan magnet. Oleh kerana penyelesaian dual wujud, analisis kestabilan temporal dijalankan untuk mengesahkan bahawa penyelesaian cabang atas stabil, manakala penyelesaian cabang bawah adalah tidak stabil.

\section{PENGHARGAAN}

Bantuan kewangan yang diterima daripada Kementerian Pendidikan Malaysia (Kod Projek: FRGS/1/2019/STG06/ UKM/01/4) dan Universiti Teknikal Malaysia Melaka amat dihargai. Kajian oleh Ioan Pop dibiayai oleh geran PN-III-P4-ID-PCE-2016-0036, UEFISCDI daripada Kementerian Sains Romania.

\section{RUJUKAN}

Ahmadi, M.H., Mirlohi, A., Alhuyi Nazari, M. \& Ghasempour, R. 2018. A review of thermal conductivity of various nanofluids. Journal of Molecular Liquids 265: 181-188.

Akilu, S., Sharma, K.V., Baheta, A.T. \& Mamat, R. 2016. A review of thermophysical properties of water based composite nanofluids. Renewable and Sustainable Energy Reviews 66: 654-678.
Awaludin, I.S., Ishak, A. \& Pop, I. 2018. On the stability of MHD boundary layer flow over a stretching/shrinking wedge. Scientific Reports 8: 13622.

Babu, J.A.R., Kumar, K.K. \& Rao, S.S. 2017. State-of-art review on hybrid nanofluids. Renewable and Sustainable Energy Reviews 77: 551-565.

Bachok, N. \& Ishak, A. 2011. Similarity solutions for the stagnation-point flow and heat transfer over a nonlinearly stretching/shrinking sheet. Sains Malaysiana 40(11): 1297 1300 .

Bachok, N., Ishak, A. \& Pop, I. 2011. Stagnation-point flow over a stretching/shrinking sheet in a nanofluid. Nanoscale Research Letters 6: 623.

Choi, S.U.S. \& Eastman, J.A. 1995. Enhancing thermal conductivity of fluids with nanoparticles. Proceedings of the 1995 ASME International Mechanical Engineering Congress and Exposition. San Francisco, CA.

Crane, L.J. 1970. Flow past a stretching plate. Zeitschrift Für Angewandte Mathematik Und Physik ZAMP 21(4): 645647.

Das, P.K. 2017. A review based on the effect and mechanism of thermal conductivity of normal nanofluids and hybrid nanofluids. Journal of Molecular Liquids 240: 420-446.

Das, S.K., Choi, S.U.S., Yu, W. \& Pradeep, T. 2007. Nanofluids: Science and Technology. New Jersey: Wiley-Interscience.

Devi, S.S.U. \& Devi, S.P.A. 2017. Heat transfer enhancement of $\mathrm{Cu}-\mathrm{Al}_{2} \mathrm{O}_{3}$ /water hybrid nanofluid flow over a stretching sheet. Journal of the Nigerian Mathematical Society 36(2): 419-433.

Devi, S.P.A. \& Devi, S.S.U. 2016. Numerical investigation of hydromagnetic hybrid $\mathrm{Cu}-\mathrm{Al}_{2} \mathrm{O}_{3}$ /water nanofluid flow over a permeable stretching sheet with suction. International Journal of Nonlinear Sciences and Numerical Simulation 17(5): 249-257.

Dinarvand, S. 2019. Nodal/saddle stagnation-point boundary layer flow of $\mathrm{CuO}-\mathrm{Ag} /$ water hybrid nanofluid: A novel hybridity model. Microsystem Technologies. m.s. 1-15.

Fang, T.G., Zhang, J. \& Yao, S.S. 2009. Viscous flow over an unsteady shrinking sheet with mass transfer. Chinese Physics Letters 26(1): 2-5.

Ghadikolaei, S.S., Yassari, M., Sadeghi, H., Hosseinzadeh, K. \& Ganji, D.D. 2017. Investigation on thermophysical properties of $\mathrm{TiO}_{2}-\mathrm{Cu} / \mathrm{H}_{2} \mathrm{O}$ hybrid nanofluid transport dependent on shape factor in MHD stagnation point flow. Powder Technology 322: 428-438.

Goldstein, S. 1965. On backward boundary layers and flow in converging passages. Journal of Fluid Mechanics 21(1): 33-45.

Harris, S.D., Ingham, D.B. \& Pop, I. 2009. Mixed convection boundary-layer flow near the stagnation point on a vertical surface in a porous medium: Brinkman model with slip. Transport in Porous Media 77(2): 267-285. 
Hayat, T. \& Nadeem, S. 2017. Heat transfer enhancement with $\mathrm{Ag}-\mathrm{CuO} /$ water hybrid nanofluid. Results in Physics 7: 2317-2324.

Hayat, T., Nadeem, S. \& Khan, A.U. 2018. Rotating flow of Ag$\mathrm{CuO} / \mathrm{H}_{2} \mathrm{O}$ hybrid nanofluid with radiation and partial slip boundary effects. European Physical Journal E 41(6): 75.

Hiemenz, K. 1911. Die Grenzschicht an einem in den gleichförmigen Flüssigkeitsstrom eingetauchten geraden Kreiszylinder. Dinglers Polytechnisches Journal 326: 321 410.

Homann, F. 1936. Der Einflub grober Zähigkeit bei der Strömung um den Zylinder und um die Kugel. Zeitschrift für Angewandte Mathematik und Mechanik 16: 153-164.

Howarth, L. 1951. The boundary layer in three dimensional flow. -Part II. The flow near a stagnation point. Philosophical Magazine and Journal of Science 42(335): 1433-1440.

Huminic, G. \& Huminic, A. 2018. Hybrid nanofluids for heat transfer applications - A state-of-the-art review. International Journal of Heat and Mass Transfer 125: 82-103.

Ishak, A., Nazar, R. \& Pop, I. 2008. Dual solutions in mixed convection flow near a stagnation point on a vertical surface in a porous medium. International Journal of Heat and Mass Transfer 51(5-6): 1150-1155.

Jamshed, W. \& Aziz, A. 2018. Cattaneo - Christov based study of $\mathrm{TiO}_{2}-\mathrm{CuO} / \mathrm{EG}$ Casson hybrid nanofluid flow over a stretching surface with entropy generation. Applied Nanoscience 8(4): 685-698.

Jusoh, R., Nazar, R. \& Pop, I. 2019. Impact of heat generation/ absorption on the unsteady magnetohydrodynamic stagnation point flow and heat transfer of nanofluids. International Journal of Numerical Methods for Heat \& Fluid Flow. https://doi.org/10.1108/HFF-04-2019-0300.

Kamal, F., Zaimi, K., Ishak, A. \& Pop, I. 2019. Stability analysis of MHD stagnation-point flow towards a permeable stretching/shrinking sheet in a nanofluid with chemical reactions effect. Sains Malaysiana 48(1): 243-250.

Khashi'ie, N.S., Arifin, N.M., Nazar, R., Hafidzuddin, E.H., Wahi, N. \& Pop, I. 2019. A stability analysis for magnetohydrodynamics stagnation point flow with zero nanoparticles flux condition and anisotropic slip. Energies 12(7): 1268.

Kechil, S.A. \& Hashim, I. 2009. Approximate analytical solution for MHD stagnation-point flow in porous media. Communications in Nonlinear Science and Numerical Simulation 14(4): 1346-1354.

Khanafer, K., Vafai, K. \& Lightstone, M. 2003. Buoyancy-driven heat transfer enhancement in a two-dimensional enclosure utilizing nanofluids. International Journal of Heat and Mass Transfer 46(19): 3639-3653.

Leong, K.Y., Ku Ahmad, K.Z., Ong, H.C., Ghazali, M.J. \& Baharum, A. 2017. Synthesis and thermal conductivity characteristic of hybrid nanofluids - A review. Renewable and Sustainable Energy Reviews 75: 868-878.
Lok, Y.Y., Ishak, A. \& Pop, I. 2011. MHD stagnation point flow with suction towards a shrinking sheet. Sains Malaysiana 40(10): 1179-1186.

Mahian, O., Kolsi, L., Amani, M., Estellé, P., Ahmadi, G., Kleinstreuer, C., Marshall, J.S., Siavashi, M., Taylor, R.A., Niazmand, H., Wongwises, S., Hayat, T., Kolanjiyil, A., Kasaeian, A. \& Pop, I. 2019a. Recent advances in modeling and simulation of nanofluid flows - Part I: Fundamentals and theory. Physics Reports 790: 1-48.

Mahian, O., Kolsi, L., Amani, M., Estellé, P., Ahmadi, G., Kleinstreuer, C., Marshall, J.S., Taylor, R.A., Abu-nada, E., Rashidi, S., Niazmand, H., Wongwises, S., Hayat, T., Kasaeian, A. \& Pop, I. 2019b. Recent advances in modeling and simulation of nanofluid flows - Part II: Applications. Physics Reports 791: 1-59.

Merkin, J.H. 1980. Mixed convection boundary layer flow on a vertical surface in a saturated porous medium. Journal of Engineering Mathematics 14(4): 301-313.

Miklavčič, M. \& Wang, C.Y. 2006. Viscous flow due to a shrinking sheet. Quarterly of Applied Mathematics 64(2): 283-290.

Mohamed, M.K.A., Salleh, M.Z., Nazar, R. \& Ishak, A. 2012. Stagnation point flow over a stretching sheet with Newtonian heating. Sains Malaysiana 41(11): 1467-1473.

Oztop, H.F. \& Abu-Nada, E. 2008. Numerical study of natural convection in partially heated rectangular enclosures filled with nanofluids. International Journal of Heat and Fluid Flow 29(5): 1326-1336.

Rashidi, M.M. \& Erfani, E. 2011. A new analytical study of MHD stagnation-point flow in porous media with heat transfer. Computers and Fluids 40(1): 172-178.

Raza, J., Rohni, A. \& Omar, Z. 2016. Numerical investigation of copper-water $(\mathrm{Cu}$-Water) nanofluid with different shapes of nanoparticles in a channel with stretching wall: Slip effects. Mathematical and Computational Applications 21(4): 43.

Rosali, H., Ishak, A. \& Pop, I. 2011. Stagnation point flow and heat transfer over a stretching/shrinking sheet in a porous medium. International Communications in Heat and Mass Transfer 38(8): 1029-1032.

Roşca, A.V., Roşca, N.C. \& Pop, I. 2014. Note on dual solutions for the mixed convection boundary layer flow close to the lower stagnation point of a horizontal circular cylinder: Case of constant surface heat flux. Sains Malaysiana 43(8): 1239-1247.

Rosca, N.C., Grosan, T. \& Pop, I. 2012. Stagnation-point flow and mass transfer with chemical reaction past a permeable stretching/shrinking sheet in a nanofluid. Sains Malaysiana 41(10): 1271-1279.

Rostami, M.N., Dinarvand, S. \& Pop, I. 2018. Dual solutions for mixed convective stagnation-point flow of an aqueous silica-alumina hybrid nanofluid. Chinese Journal of Physics 56(5): 2465-2478. 
Sajid, M.U. \& Ali, H.M. 2019. Recent advances in application of nanofluids in heat transfer devices: A critical review. Renewable and Sustainable Energy Reviews 103: 556592.

Sajid, M.U. \& Ali, H.M. 2018. Thermal conductivity of hybrid nanofluids: A critical review. International Journal of Heat and Mass Transfer 126: 211-234.

Sakiadis, B.C. 1961. Boundary-layer behaviour on continuous solid surfaces: I. Boundary layer equations for twodimensional and axisymmetric flow. American Institute of Chemical Engineers Journal 7(1): 26-28.

Sarkar, J., Ghosh, P. \& Adil, A. 2015. A review on hybrid nanofluids: Recent research, development and applications. Renewable and Sustainable Energy Reviews 43: 164-177.

Shampine, L.F., Gladwell, I. \& Thompson, S. 2003. Solving ODEs with MATLAB. Cambridge University Press. Cambridge: Cambridge University Press.

Sidik, N.A.C., Adamu, I.M., Jamil, M.M., Kefayati, G.H.R., Mamat, R. \& Najafi, G. 2016. Recent progress on hybrid nanofluids in heat transfer applications: A comprehensive review. International Communications in Heat and Mass Transfer 78: 68-79.

Soid, S.K., Ishak, A. \& Pop, I. 2018. MHD stagnation-point flow over a stretching/shrinking sheet in a micropolar fluid with a slip boundary. Sains Malaysiana 47(11): 2907-2916.

Subhani, M. \& Nadeem, S. 2018. Numerical analysis of micropolar hybrid nanofluid. Applied Nanoscience 9: 447459.

Sundar, L.S., Sharma, K.V., Singh, M.K. \& Sousa, A.C.M. 2017. Hybrid nanofluids preparation, thermal properties, heat transfer and friction factor - A review. Renewable and Sustainable Energy Reviews 68: 185-198.

Tiwari, R.K. \& Das, M.K. 2007. Heat transfer augmentation in a two-sided lid-driven differentially heated square cavity utilizing nanofluids. International Journal of Heat and Mass Transfer 50(9-10): 2002-2018.

Usman, M., Hamid, M., Zubair, T., Haq, R.U. \& Wang, W. 2018. $\mathrm{Cu}-\mathrm{Al}_{2} \mathrm{O}_{3} /$ Water hybrid nanofluid through a permeable surface in the presence of nonlinear radiation and variable thermal conductivity via LSM. International Journal of Heat and Mass Transfer 126: 1347-1356.

Waini, I., Ishak, A. \& Pop, I. 2019a. Unsteady flow and heat transfer past a stretching/shrinking sheet in a hybrid nanofluid. International Journal of Heat and Mass Transfer 136: 288-297.

Waini, I., Ishak, A. \& Pop, I. 2019b. Flow and heat transfer along a permeable stretching/shrinking curved surface in a hybrid nanofluid. Physica Scripta 94(10): 105219.

Waini, I., Ishak, A. \& Pop, I. 2019c. Hybrid nanofluid flow and heat transfer over a nonlinear permeable stretching/ shrinking surface. International Journal of Numerical Methods for Heat \& Fluid Flow: https://doi.org/10.1108/ HFF-01-2019-0057.
Waini, I., Ishak, A. \& Pop, I. 2019d. Hybrid nano fluid flow and heat transfer past a vertical thin needle with prescribed surface heat flux. International Journal of Numerical Methods for Heat \& Fluid Flow. https://doi.org/10.1108/ HFF-04-2019-0277.

Waini, I., Ishak, A. \& Pop, I. 2019e. On the stability of the flow and heat transfer over a moving thin needle with prescribed surface heat flux. Chinese Journal of Physics 60: 651-658.

Wang, C.Y. 2008. Stagnation flow towards a shrinking sheet. International Journal of Non-Linear Mechanics 43(5): 377-382.

Wang, C.Y. 1990. Liquid film on an unsteady stretching surface. Quarterly of Applied Mathematics 48(4): 601-610.

Weidman, P.D., Kubitschek, D.G. \& Davis, A.M.J. 2006. The effect of transpiration on self-similar boundary layer flow over moving surfaces. International Journal of Engineering Science 44(11-12): 730-737.

Yih, K.A. 1998. The effect of uniform suction/blowing on heat transfer of magnetohydrodynamic Hiemenz flow through porous media. Acta Mechanica 130(3-4): 147158.

Yousefi, M., Dinarvand, S., Eftekhari Yazdi, M. \& Pop, I. 2018. Stagnation-point flow of an aqueous titania-copper hybrid nanofluid toward a wavy cylinder. International Journal of Numerical Methods for Heat and Fluid Flow 28(7): 17161735.

Zaimi, W.M.K.A. \& Ishak, A. 2012. Stagnation flow of a micropolar fluid towards a vertical permeable surface with prescribed heat flux. Sains Malaysiana 41(10): 1263 1270.

\section{Iskandar Waini}

Fakulti Teknologi Kejuruteraan Mekanikal dan Pembuatan Universiti Teknikal Malaysia Melaka

Hang Tuah Jaya

76100 Durian Tunggal, Melaka

Malaysia

\section{Anuar Ishak*}

Pusat Pengajian Sains Matematik

Fakulti Sains dan Teknologi

Universiti Kebangsaan Malaysia

43600 UKM Bangi, Selangor Darul Ehsan

Malaysia

Ioan Pop

Department of Mathematics

Babeş-Bolyai University

400084 Cluj-Napoca

Romania

*Pengarang untuk surat-menyurat: anuar_mi@ukm.edu.my

Diserahkan: 18 Mac 2019

Diterima: 17 Oktober 2019 